\title{
Decolonization for Ethnomusicology and Music Studies in Higher Education
}

\author{
Luis Chávez \\ University of California, Davis (USA) \\ Russell P. Skelchy \\ University of Nottingham (UK)
}

The word decolonization often is used metaphorically in scholarship in the humanities to describe an array of processes involving social justice, resistance, sustainability and preservation. We argue against using decolonization as metaphor because decolonization demands a level of political engagement different from other social justice projects. Decolonization refers to a radical transformation in relations of power, worldviews, and, in an academic context, our role as scholars and our relationship to the university system as an industry. This article interrogates how the word decolonization has been used by ethnomusicologists in previous publications and argues that a discourse of decolonizing music studies and ethnomusicology should not propagate the term as a descriptive signifier while overlooking the issues mentioned above. Excerpts from interviews with three former Society for Ethnomusicology (SEM) presidents are presented for readers to interpret how these people in seats of power are thinking about decolonizing music studies. We conclude by suggesting ten practical approaches and projects that begin to address what decolonization involves and how it can be done.

Keywords: coloniality, music studies, music education, ethnomusicology, musicology, decolonization

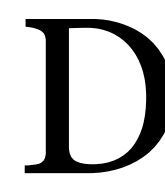

ecolonization is not a new topic to ethnomusicology. It has been the theme of a past national conference of the Society for Ethnomusicology (SEM), a US-based organization, and more recently a topic covered by SEM Student News. The SEM national conference in 2006, hosted by the University of Hawai'i, featured the theme of decolonization and included a number of panels that addressed the topic-among them: "Decolonizing American Indian Transcription," "Decolonizing Music of the Pacific," "Decolonizing Music Schol-

(C) Luis Chávez and Russell P. Skelchy. The content of this article is the sole responsibility of the author. The ACT Journal and the Mayday Group are not liable for any legal actions that may arise involving the article's content, including, but not limited to, copyright infringement. 
arship," "Decolonizing Hawaiian Ethnomusicology" and "Decolonizing Native American Music." The usage of decolonization in the conference program focused on ideas about research methodology and indigenous representation. In addressing these two topics concerning the discourse of decolonization in ethnomusicology, these panels failed to address broader disciplinary issues and their political implications, assuming decolonization to be an abstract theoretical and apolitical process. Part of the issue is that the impulse to theorize in ethnomusicology has contributed to the abstraction of decolonization from practical applications in teaching, research methodology, and ethnographic representation. Our focus in this article is on decolonizing music studies as a starting point. Although we are acutely aware that decolonization is implicated in wider sociopolitical issues, our focus is music studies. By music studies, we include departments other than music (e.g., anthropology, performance studies), because the focus of music departments in North America traditionally is limited to composition, music history, music education, and sometimes ethnomusicology. We do not focus solely on music departments, because it has been our experience that composition and music history default to Western European music traditions, which creates a hegemonic relationship with anything outside of these practices as "Other" or "extended techniques." Specifically, our concern here is with music studies in higher education and in this context, we consider all forms of music studies as music education, including ethnomusicology. The link between ethnomusicology and music education has been the practical application of the highly contested term "world music" (Schippers 2010, 17). "World music" gained circulation in the 1960 s to describe a hands-on approach to ethnomusicology at Wesleyan University, where Robert E. Brown, building on a format pioneered in the $1950 \mathrm{OS}$ by $\mathrm{Ki}$ Mantle Hood, introduced practical music making into degree programs (Brown 1995). Since that time, musical practices and master musicians from other cultures have become a significant component of most leading U.S. ethnomusicology programs (Schippers 2010, 18). We pay particular attention to ethnomusicology because, as a discipline that has focused on teaching and studying music making practices and traditions from around the world, we believe it has the potential to be a decolonizing project of music studies. Responding to the election of Donald J. Trump as president of the United States in 2016, some U.S. ethnomusicologists have concluded that teaching ethnomusicology is an inherently political act, more crucial now than ever because it champions the cause of cultural diversity, inclu-

Chávez, Luis, and Russell P. Skelchy. 2019. Decolonization for ethnomusicology and music studies in higher education. Action, Criticism, and Theory for Music Education 18 (3): 115-43. https://doi.org/10.22176/act18.3.115 
sivity, and tolerance. While some of this may be true, we question how such discourse within the discipline continues to romanticize the perspectives of EuroAmerican liberalism while ostensibly upholding the status quo of multiculturalist institutional imperatives.

\section{Positionality Statements}

\section{Russell Skelchy:}

My interest in studying music began not long after my family emigrated to the United States from Malaysia. In the Chicago suburb where I grew up, I took piano lessons in a cramped back room of the local music instrument shop-a space that introduced me to performing Western art music and popular music. As a teenager I joined Chicago area hardcore punk scenes and employed their DIY (Do-ItYourself) ethos to learn about the political role of music. In graduate studies at the University of California, Riverside, I became the first PhD student in the ethnomusicology program to complete a concurrent master's degree in Southeast Asian Studies. This interdisciplinary background enabled my teaching and research interests in popular music, sound, colonialism and ethnicity; however, it has also contributed to my questioning of how I engage with academic research methodologies and knowledge production. My experiences as an immigrant continue to shape how I think about imperialism and contemporary education.

\section{Luis Chávez:}

My relationship with academe constantly changed throughout my five years as a PhD student at the University of California, Davis, in Music and Native American Studies. During the first two years of graduate work, I maintained definite boundaries between my relationships with other researchers, and musicians in punk, DIY, and anarchist communities. Prior to entering college and my graduate studies, I participated in a DIY ethos as a teenager, shaping my earliest experiences of making music. In January 2015, my position changed within the community of ethnomusicologist graduate students when I started writing my dissertation prospectus, and I began to ask critical questions about my relationship with my project. As a first generation born in the United States (Mexican Californian) writing on norteño music styles and Mexican indigeneity, my role as researcher became more integrated into my intimate relationships and personal life, each mutually changing one another, and I began to see myself more in my

Chávez, Luis, and Russell P. Skelchy. 2019. Decolonization for ethnomusicology and music studies in higher education. Action, Criticism, and Theory for Music Education 18 (3): 115-43. https://doi.org/10.22176/act18.3.115 
project. My personal experience continually shapes my relation to the field of ethnomusicology and my students.

\section{Differentiating Decolonization from Social Justice}

The word decolonization is often used metaphorically in scholarship in the humanities and disciplines such as education studies to describe an array of processes involving social justice, resistance, sustainability, and preservation (Tuck and Yang 2012, Bishop 2005, Cook-Lynn 1998). Decolonization in ethnomusicology and music studies is not a metaphor, however, because decolonization demands a level of political engagement and structural fracture from these other pedagogical projects. Although we acknowledge the value of the social justice work in which these projects engage, it is important to make a political distinction between decolonization and the reformist approaches of these other projects. While decolonization and social justice projects may overlap in tactics, there are distinct differences between the two in terms of political outcomes. As Tuck and Yang observe, "Decolonization ... is a distinct project from other civil and human rights-based social justice projects ... [that] is far too often subsumed into the directives of these projects, with no regard for how decolonization wants something different than those forms of justice" (Tuck and Yang 2012, 2). The language of decolonization has been superficially adopted into fields such as education and other social sciences, supplanting prior discourse and ways of talking about social justice, critical methodologies, or approaches which decenter settler perspectives. Projects like social justice and human rights-based reforms are abstract because they center on ideas related to Western jurisprudence. This is problematic because definitions of justice and rights are often interpreted differently in other parts of the world. We hope to keep open the possibility of listening to other interpretations of jurisprudence to avoid applying universalist applications.

Decolonization for music studies engages with 1) decentering western art music as the focus of music studies, 2) listening to and implementing indigenous and non-Eurocentric methodologies and knowledge systems, and 3) implementing decolonizing approaches in the classroom and in research practice. Choosing to ignore or engage with decolonizing approaches is an inherently political choice for educators and scholars. The casual use of phrases such as "decolonizing think-

Chávez, Luis, and Russell P. Skelchy. 2019. Decolonization for ethnomusicology and music studies in higher education. Action, Criticism, and Theory for Music Education 18 (3): 115-43. https://doi.org/10.22176/act18.3.115 
ing" or "decolonizing schools" often overlooks the political context of contributions made by indigenous intellectuals and activists to theories and frameworks of decolonization or the immediate context of settler colonialism in geographical spaces such as North America. As Tuck and Yang (2012) suggest,

Decolonize (a verb) and decolonization (a noun) cannot easily be grafted onto pre-existing discourses/frameworks, even if they are critical, even if they are anti-racist, even if they are justice frameworks.... When we write about decolonization, we are not offering it as a metaphor.... Decolonization is not a swappable term for other things we want to do to improve our societies and schools. Decolonization doesn't have a synonym. (3)

As ethnomusicologists engage more deeply with issues of political activism, community engagement, proactive pedagogies, race relations, repatriation, class consciousness, power dynamics, violent conflict, disability, spirituality, and social justice, we question how decolonization can enable us to address our role within a changing academic setting. This article interrogates how the word decolonization has been used in selected ethnomusicological publications and argues that a discourse of decolonizing ethnomusicology should not propagate the term as a descriptive signifier that overlooks the issues previously mentioned. Furthermore, we trace how decolonization has been defined in fields such as Native American Studies and Postcolonial Studies to discuss and analyze comments from interviews we conducted with former SEM presidents on the issue of decolonization, music studies, and ethnomusicology. We conclude with a list of projects ethnomusicologists and other music educators may use to decolonize practices in the classroom and in fieldwork.

\section{Keyword: Decolonization}

Decolonization demands fundamental changes in relations of power, worldviews, the role of scholars, and our relationships to the university system as an industry. It forces long-overdue conversations about the historical relationships that universities such as Harvard and Brown have with slavery (Graham 2017). Although Ivy League schools' connections to slavery have generated headlines, research has shown that for over 200 years, many universities in the United States-southern and northern, public and private-had ties to the business of slavery. As Harvard president Drew Gilpin Faust recently acknowledged, "This history, and its legacy has shaped our institution in ways that we have yet to fully understand."

Chávez, Luis, and Russell P. Skelchy. 2019. Decolonization for ethnomusicology and music studies in higher education. Action, Criticism, and Theory for Music Education 18 (3): 115-43. https://doi.org/10.22176/act18.3.115 
Land grants given through the Morrill Act of 1862 were intended to establish universities and colleges that were tuition-free or virtually free. The University of California system, for instance, had free tuition for students until the 1980 s (Wittner 2015). The increasingly corporatized, profit-driven model used by many public universities today represents the changing role of these institutions in education and the communities they serve. Furthermore, the university's relationship to land, according to this worldview, illustrates how capitalism-the commodification of land and education-implicates students in this colonial relationship. As Linda Tuhiwai Smith (2008) argues, "decolonization, once viewed as the formal process of handing over the instruments of government, is now recognized as a long-term process involving the bureaucratic, cultural, linguistic, and psychological divesting of colonial power" (98). Divestment of colonial power involves the repatriation of land and resources, thereby transforming existing paradigms of power and privilege created by settler colonialists.

In Native American studies, decolonization involves two modes of thought drawing from indigenous theory; the first involves histories of colonization of land and resources in settler colonialism. The term settler colonialism (or settlerism) describes "created systems of power that aim to expropriate indigenous territories and eliminate modes of production in order to replace indigenous peoples with settlers who are discursively constituted as superior and therefore more deserving over these contested lands and resources" (Saranillio 2015, 284). The second mode of thought focuses on autonomy and self-determination, which addresses access to land, resources, and representations of indigenous communities from within. Decolonization in this context is about rethinking relationships between land and community. Autonomy over land is not about mirroring the frameworks of the nation-state but challenging existing colonial ideas about property and ownership by asserting native perspectives.

Postcolonial scholarship questions master narratives and the idea of a universal standpoint on knowledge production, in many cases refuting or creating counterpoint to knowledges produced within Euro-American discourses (Anderson, Khan, Reimer-Kirkham 2011, 24). The term decolonization has been used in postcolonial studies to describe: 1) a periodic (time) marker describing pre- and post-formal colonization, and 2) a response to a colonial past that remains operational in the institutions and forms of governance in the postcolonial nationstate. Early scholarship in the field describes the ways indigenous people have

Chávez, Luis, and Russell P. Skelchy. 2019. Decolonization for ethnomusicology and music studies in higher education. Action, Criticism, and Theory for Music Education 18 (3): 115-43. https://doi.org/10.22176/act18.3.115 
replicated roles previously held by Euro-American colonizers. Decolonization, as we use the term, refers to a re-thinking of the institutions and structures left over from the formal colonial period.

Thinking critically about the history of colonialism has led some scholars to connect the ideas of ontology and power, and specifically for Walter Mignolo, to the idea of "coloniality," which describes how colonial relations of power left a profound impact not only on systems of governance, authority, sexuality, knowledge, and economy but on a general understanding of being (Mignolo 2000, Quijano 2000, Maldonado-Torres 2007). In this context, there are differences between colonialism and coloniality. While colonialism refers primarily to a political and economic relation in which the sovereignty of a people or nationstate rests on the power of another nation, coloniality describes "the longstanding patterns of power that emerged as a result of colonialism, but that define culture, labor, intersubjective relations, and knowledge production well beyond the strict limits of colonial administration" (Maldonado-Torres 2007, 243). Coloniality survives colonialism because it resonates in academic books, criteria for academic performance, cultural patterns and in the self-image and aspirations of colonized people. As the residual form or aftermath of colonial encounter, coloniality emerged in a specific socio-historical setting of discovery and conquest, especially in places like the Americas. As Aníbal Quijano (2007) describes, "Coloniality is still the most general form of domination in the world today, once colonialism as an explicit political order was destroyed. It doesn't exhaust, obviously, the conditions nor the modes of exploitation and domination between peoples. But it hasn't ceased to be, for 500 years, their main framework" (170). Coloniality is expressed in various ways; for instance, "coloniality of power," as Quijano suggests, is conceived together with the social classification of race that differentiated the colonizers from the colonized in terms of social identities and physiognomic traits and functions in a world capitalist system (Quijano 2007, 171). Furthermore, as Mignolo (2000) suggests, coloniality of knowledge describes the impact of colonization on different areas of knowledge production (e.g., science, language) that have engendered coloniality of being (colonialidad de ser) (669). Logics of coloniality also operate within music education, for instance in the historical hegemony of Western canon genres, repertoire, ensembles and educational practices that perpetuate European colonial worldviews of the body, knowledge and cultural stereotypes (Rosabal-Coto 2014, 174-5).

Chávez, Luis, and Russell P. Skelchy. 2019. Decolonization for ethnomusicology and music studies in higher education. Action, Criticism, and Theory for Music Education 18 (3): 115-43. https://doi.org/10.22176/act18.3.115 
A more nuanced understanding of the words decolonization and coloniality as they are used in Native American and postcolonial studies suggests ways that ethnomusicologists and music educators can further address the legacy of Eurocentric thinking in each of the following areas: North American music studies, whiteness and white supremacy. In popular culture of the United States, the term "white supremacy" is often associated historically with groups such as the $\mathrm{Ku}$ Klux Klan, who manifested the ideologies of white supremacy, more recently framed as "white nationalism." In the context of music studies, we are not referring specifically to these groups but rather to the idea that music education in the U.S. is systematically centered on Euro-Western art music traditions and pedagogic practices that promote and instill specific cultural values and standards based on particular ethnic, class, and gender backgrounds. By upholding the supremacy of Euro-Western art music, many music departments have upheld the political structures of white supremacy in music studies historically and in current practice (Hess 2017, Bradley 2015, Gustafson 2009). In some instances, adding ethnic diversity (through the recruitment and hiring of faculty, staff, and students) to music (and other) departments has been implemented as a means of addressing and overcoming structural inequality. These efforts, however wellintentioned, have not (and will not) change the existing paradigm if white supremacist values are not decentered. In this scenario, it is possible to envision a music department consisting entirely of non-white people, even in seats of power, that retains the existing political and cultural order of white supremacy. Speaking in the context of Black liberation movements in the U.S., Samudzi and Anderson (2018) suggest that,

diversity ... will not solve our problem. Simply because someone shares race, gender or another aspect of identity does not guarantee loyalty or that they will act in the interests of Black communities ... the rhetorics of "diversity" and "inclusion" [in a U.S. political context] merely enable nominal representation (or a mitigation of material harms in some cases) as opposed to liberation in any real sense. (13)

Critical indigenous gender, sexuality, and feminist studies have also confronted the ways that colonialism and imperialism, especially in the United States and Canada, have required indigenous people to fit within heteronormative archetypes of authentic indigeneity. Using racialized, gendered, and sexualized images of indigenous women/femininity and men/masculinity within the state's logic of multicultural liberalism, indigenous people are included only in "cos-

Chávez, Luis, and Russell P. Skelchy. 2019. Decolonization for ethnomusicology and music studies in higher education. Action, Criticism, and Theory for Music Education 18 (3): 115-43. https://doi.org/10.22176/act18.3.115 
tumed affiliation" (Barker 2017, 3). Critical Indigenous Studies scholars have argued that understanding decolonization projects in which indigenous land, ecosystems, and bodies are at stake must also confront the consequences of the global military and energy industrial complexes through their cultural perspectives and practices (Simpson 2012; LaDuke and Cruz 2011; Nelson 2011). In this context, decolonization must address the oppression, exploitation, and violent holocaust of indigenous peoples that continues today, and therefore, indigenous people have taken on decolonization projects that include mind, body, and spirituality "in the remembrance and reform of their relations and responsibilities to the lands and ecosystems in which they live and to the other beings to whom they are related" (Barker 2017, 26).

\section{Keyword: Ethnomusicology}

In the mid-1950s, the founding of the Society for Ethnomusicology (SEM) emphasized the approach of the cultural study of music rather than that of comparative musicology. At the time, musician historians were generally ambivalent to the idea that students of non-Western music could contribute to music studies (Nettl 2010, 96). Ethnomusicologists responded by creating SEM, the Ethnomusicology Newsletter, and establishing a "school of ethnomusicology" that focused on music of non-Western cultures from the perspective of Western art music historians and music departments (ibid). Early curricula in ethnomusicology drew from music traditions with well-documented theoretical traditions comparable to those of Europe. Notated classical traditions of India, Java (Indonesia), the Middle East, and China fit the paradigm and standards of Western art music and therefore drew considerable attention. Since most music historians were expected to exhibit a minimum competence in performing Western music, performance also became central for Americans teaching non-Western traditions. As Radano and Olaniyan (2016) observe, "What might have taken shape according to a myriad of approaches frequently conformed to the interpretive models grounded in the study of European art music" (11). The study of world music became an alternative to classical music repertory, allowing students to achieve fluency in a "foreign music," modeled after foreign language study.

Part of this process included constructing ethnomusicology as a research discipline located in the academic world. Comparative musicology, at the time, fo-

Chávez, Luis, and Russell P. Skelchy. 2019. Decolonization for ethnomusicology and music studies in higher education. Action, Criticism, and Theory for Music Education 18 (3): 115-43. https://doi.org/10.22176/act18.3.115 
cused on empirical research methodologies based on universalist ideologies. It was understood as the study of "primitive music" (Titon 2015, 13), and its purpose was to increase knowledge of the world's peoples. Jaap Kunst's book, EthnoMusicology (1950) defined the burgeoning field of ethnomusicology as the study of "all tribal and folk music of every kind of non-Western art music ... as well [as] the sociological aspects of music" (1). As Jeff Titon (2015) suggests, this name change was based on the redundancy of the word "comparative;" however, the research concerns for ethnomusicology remained the same (13-14). The name change, although insignificant as a new research methodology, nevertheless opened the space for an emphasis on the cultural study of music. Since that time, mainstream histories of ethnomusicology have continued to position ethnomusicology as a discipline centered in the academic world. This focus has also positioned applied ethnomusicology as marginal in comparison to its predecessor, comparative musicology (ibid). Comparative musicology continued to exert a significant influence on ethnomusicology in its early decades from 1950 to 1980 (Nettl 2010, 160-5). The founding of the society created a new name for the discipline that oriented it towards anthropology (at the time) and signaled the "significant and enduring new direction of the field" (Titon 2015, 16).

Even with the establishment of a society, ethnomusicology continued to be on the fringe of the academic world. It existed only as an individual course offered through departments such as anthropology and music. For ethnomusicology to be considered a science, it needed to be legitimized within the university as a research science intended specifically to increase knowledge on musics of the world. The few professors of ethnomusicology that could advise on doctoral dissertations established curricula and academic graduate programs to proliferate scholars in the discipline, with the ultimate goal of establishing tenure track positions within music departments. All this solidified ethnomusicology's position as an academic pursuit.

Ethnomusicologists have whispered about decolonization since at least 2006. Few publications in the discipline, however, have directly addressed the topic. In the seminal text, Shadows in the Field, Gregory Barz and Timothy Cooley (2008) describe a shift during the 1970 s in ethnographic disciplines such as ethnomusicology, anthropology, folklore, sociology, and performance studies, initiated by challenges to Western thought during the period after European colonial rule. In their interpretation, decolonization appeared as a periodic phenomenon linked

Chávez, Luis, and Russell P. Skelchy. 2019. Decolonization for ethnomusicology and music studies in higher education. Action, Criticism, and Theory for Music Education 18 (3): 115-43. https://doi.org/10.22176/act18.3.115 
specifically to the postcolonial era. Barz and Cooley (2008) position fieldwork in ethnomusicology as a postcolonial ethnographic project based on experience and self-critical evaluation, as a result of coming to terms with the colonial legacy of many academic disciplines and their interpretations and representations (11). Another treatment of decolonization, these authors suggest, is the decolonization of departments and schools of music and of the university structure generally (23).

Although Shadows in the Field focuses on fieldwork and representation as a colonizing enterprise, a deeper engagement with the processes of decolonization are not directly addressed. Although some ethnomusicologists acknowledge that these "shadows" are deeply shaped by colonialism, many have yet to address how decolonization is to be done or what the political ramifications of decolonizing are for the discipline and for how ethnomusicologists engage with the communities within which they work and live. At this point, the impact of colonialism on ethnomusicology is a topic largely agreed upon; however, it is our view that ethnomusicologists have yet to fully address these issues.

Barz and Cooley (2008) also observe that "graduate students are a good indicator of disciplinary change" (12). This appears to be true for addressing current issues about decolonization. A recent issue of SEM Student News (Volume 12.2, Fall/Winter 2016), a publication by graduate students in ethnomusicology, devoted the entire issue to students' thoughts about decolonization in relation to ethnomusicology, students' roles, and experiences in decolonizing ethnomusicology, and the influence of indigenous (or "non-Western") ways of knowing. The collective voices in this issue addressed the concern that colonialism and its legacies continue to reach into our daily lives. Contributors to this issue came from thirteen countries around the world ranging from North America, Asia, the Middle East, and Central and South America. These contributors discussed issues that included decentering ethnomusicology from the United States and Europe, recognizing privilege and power, and constructing spaces to talk about decolonizing ethnomusicology. It was generally accepted that recognizing privilege and power was an important first step toward decolonizing ethnomusicology. The scope of discussion in this publication pointed to a more nuanced and detailed engagement with decolonization in ethnomusicology, starting with the three issues of land ownership, methodology, and white privilege. Critiquing ethnomusicology is not necessarily new to the discipline. As Nettl (2010) writes,

Chávez, Luis, and Russell P. Skelchy. 2019. Decolonization for ethnomusicology and music studies in higher education. Action, Criticism, and Theory for Music Education 18 (3): 115-43. https://doi.org/10.22176/act18.3.115 
"ethnomusicologists, more perhaps than people in other disciplines, devote their energy to criticizing the course of their field. ... One might say that the practice of critiquing the discipline as a whole is part of their identity" (54-5). The critique of ethnomusicology offered by graduate students in this publication, however, went beyond the disciplinary lens Nettl described to address wider issues of institutional power and the idea that ethnomusicology in the U.S. continues to ignore certain voices.

\section{Enduring Shadows}

Barz and Cooley published the first edition of Shadows in the Field as graduate students at Brown University in the 1990s. The volume consisted of ethnomusicologists, both graduate students and established scholars, and addressed issues related to doing fieldwork at home, ethnographic methodology, teaching, ethnomusicological pasts, and issues on race, class, and gender. Following the "crisis of interpretation" which addressed ethnographic writing, reflexivity, objectivity, and authority among anthropologists in the late 1980 s and 1990s, Shadows forced many ethnomusicologists to consider the "partiality of cultural and historical truths" and "literariness" (re)presented in ethnographies-in this sense, some interpretive social scientists began thinking of ethnographies as "true fictions" (Clifford 1986, 3-6). This shift in thinking pushed ethnomusicologists to greater reflexively about their own subjectivity, and the focus on performativity in Shadows significantly impacted how ethnomusicologists approached ethnographyfor instance, in the idea of performance as embodied knowledge. Barz and Cooley (2008) began a discussion of how ethnomusicologists do fieldwork by organizing a symposium and inviting their professors, other scholars, and graduate students to contribute to what would become Shadows.

Although the word "decolonization" is mentioned in the introduction to Shadows, the authors do not explore the topic in further detail. As we have mentioned, graduate students in ethnomusicology have recently addressed the issue more deeply in an SEM Student News publication. Issues about methodology and fieldwork remain problematic, especially for some U.S. scholars of racial or ethnic minorities, especially since people with a history of being colonized may take a more critical approach concerning issues of representation and power relations (Rodriguez 2001, Guha 1997).

Chávez, Luis, and Russell P. Skelchy. 2019. Decolonization for ethnomusicology and music studies in higher education. Action, Criticism, and Theory for Music Education 18 (3): 115-43. https://doi.org/10.22176/act18.3.115 
To better understand decolonization and the relationship to issues presented in Shadows, we interviewed Tim Cooley, one of the volume's editors. As a former SEM board member, Cooley advocated for the removal of the "Ethno-man" logo from all of the society's publications, along with the "caveman" font used in the journal Ethnomusicology. The following statements, excerpted from our interviews with Cooley, address the issue of decolonizing music studies (see Figure 1).

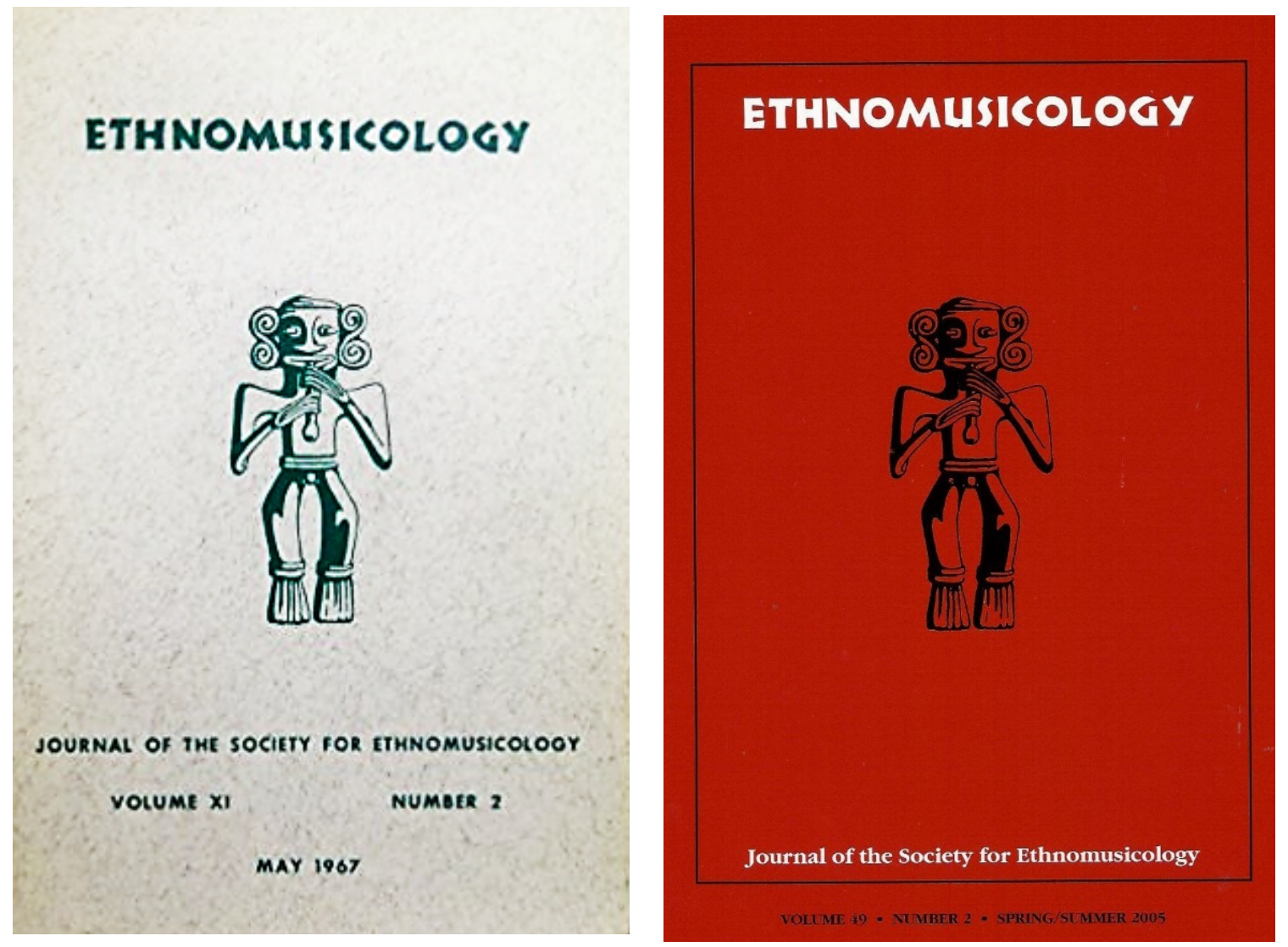

Figure 1. Covers of the journal Ethnomusicology from 1967 (left) and 2005 (right) featuring the "Ethno-man" logo.

Cooley: We have to stop indoctrinating students that the music of the European elite class is the best, is the epitome of human evolution. We have to absolutely put an end to that. I think this is relatively easy to do for academics. We have to critique the symphony orchestra, we have to critique the motivations behind propping up this very expensive ensemble, even more for the opera. It's the most elaborate and expensive performance form that I know about, and we prop it up with public funds for a very narrow, generally very privileged, segment of society. It's a classic example of government welfare for the rich. Moving money from middle class or ... the poor to the elite. That is a very controversial way to look at the symphony orchestra, symphony halls, and opera houses in our cities, but I believe it's an accurate one.

Chávez, Luis, and Russell P. Skelchy. 2019. Decolonization for ethnomusicology and music studies in higher education. Action, Criticism, and Theory for Music Education 18 (3): 115-43. https://doi.org/10.22176/act18.3.115 
Without singling out music departments, colonization, as discussed earlier, is related to the corporatized U.S. university system and to the Eurocentrism that functions within that system. Although critiquing the cultural hegemony that exists within music departments may be interpreted by some as relatively easy, the difficulty lies in initiating change that challenges the institutional power of Western art music. Cooley went on to relate this issue to English departments and their approaches to addressing Eurocentrism.

I think [other] university departments have been much quicker to decolonize than many music departments. I'd like to think of English departments [that] still teach Shakespeare but it's not the only thing they teach. The entire department is not set up to teach Shakespeare; it's not set up to reify classic English literature. I think the corollary in music departments, traditionally that has been the case. The entire [music] department is there to reify Western Art music. It's quite rare in 21st century academic departments in universities. The music department is really lagging in this.

We concur that broad discussion on social justice issues should take place in a more politically focused way consistent with decolonization, rather than an abstract concept such as social justice or reform. Decolonization should focus on practical knowledge that can be implemented and affect structural change. Practical knowledge develops a different relationship between individuals and social change. Rather than focusing on abstract principles or articles of faith, practitioners are directly connected to action that actualizes theory. For decolonization, social justice efforts and reform will be better served alongside other modes of social change, such as practical knowledge directly implemented. The last section of this article offers pedagogical projects in music studies and ethnomusicology with practical knowledge for decolonizing music education.

\section{Keyword: Engagement}

The purpose of this section is to present the thoughts of three former presidents of the Society for Ethnomusicology on decolonizing music studies. We have chosen to include long quotations from our interviewees to resist the common ethnographic practice of constructing (and controlling) representations based on selectively utilizing short excerpts from interviews. In this section, we decenter our voices as the authors in an effort to create a multivocal dialogue on what decolonizing music studies might entail. We share key excerpts during the inter-

Chávez, Luis, and Russell P. Skelchy. 2019. Decolonization for ethnomusicology and music studies in higher education. Action, Criticism, and Theory for Music Education 18 (3): 115-43. https://doi.org/10.22176/act18.3.115 
views when ethnomusicologists describe memories of decolonizing moments as an example of how they have contributed to decolonizing ethnomusicology.

We asked three main questions of the following former presidents of SEM: Beverley Diamond, Professor Emeritus in Ethnomusicology at Memorial University of Newfoundland, Native music scholar and former president of the SEM (2013-2015); Harris Berger, Director of the Research Centre for the Study of Music, Media, and Place (MMaP) at Memorial University of Newfoundland, Professor of Music and Folklore and former president of SEM (2011-2013); and Deborah Wong, Professor of Music at the University of California, Riverside, Asian American and Thai music scholar and former president of SEM (20072009).

\section{These are the questions we posed to them:}

1. Why should ethnomusicologists be concerned with decolonization? Why is this issue important for the discipline?

2. What were some of the challenges you faced in introducing (or implementing) decolonizing policies? Or, what are some of the challenges facing decolonizing policies?

3. What are the implications of decolonization for music departments? What would a decolonized music department look like for you?

We chose these questions as a starting point for not only thinking about why decolonization matters for the future of ethnomusicology and music education but also for addressing the discipline's colonialist past. Given the lack of discourse on decolonization in U.S. ethnomusicology, these scholars in leadership positions provided us with an understanding of the society's engagement with decolonization since the 2006 SEM national conference in Hawaii. These questions also addressed broader issues pertaining to music education because decolonization is not only a project of ethnomusicologists but also an interrelated endeavor with music educators. Ultimately the goal is a multifaceted project (e.g., curriculum, performance, training of scholars) to decolonize music education.

Each question will be presented with the respondent's answer. In the first question, responding to why ethnomusicologists should be concerned with decolonization, past SEM president (2013-2015) and Native music scholar Beverley Diamond explains,

Chávez, Luis, and Russell P. Skelchy. 2019. Decolonization for ethnomusicology and music studies in higher education. Action, Criticism, and Theory for Music Education 18 (3): 115-43. https://doi.org/10.22176/act18.3.115 
There are obvious things like the fact that our history is colonial, like most of the social sciences ... and the traces of that colonial history are still with us. That is reflected in references to other cultures as if they're some sort of low hanging fruit, as if you can enrich life by having more cultural diversity. That often implies that the West can access and use these cultural riches around the world for their purposes. Such celebratory statements ignore the power relationships. As ethnomusicologists we all believe diversity is a core value, a core commitment to respect different ways of living and different forms of cultural expression in the world. Within our discipline, though, and within SEM in particular, we are not nearly as diverse as I think we should be. We don't look like California or like most cities in North America, either in Canada or the US, and so although we've got a substantial international membership in SEM it's still not as diverse as say, they International Council for Traditional Music, which brings together more people from more countries every couple of years.

Diamond's comments highlight ethnomusicology's relationship to colonialism. Although she describes this colonial influence as obvious to the discipline, our experience dealing with other music scholars suggest that it remains necessary to legitimize discussions about the relationship of colonialism and music studies. Although ethnomusicologists (and music educators) have made efforts to promote cultural diversity, especially in terms of studying music as a global human phenomenon, in practice, power differentials between researchers and the communities with which we work are often not addressed. Many of the issues related to decolonizing music studies relate to coloniality, and here again it is important to differentiate coloniality from colonialism. As mentioned earlier, coloniality refers to the long-standing patterns of power that emerged as a result of colonialism. Coloniality of power survives colonialism in the ways that knowledge continues to be a product of the subject-object relationship in research (Quijano 2007, 171). Furthermore, as Diamond suggests, the lack of diversity within SEM generally and specifically in positions of power remains at issue. This lack of diversity represents how coloniality of power continues to be expressed in academic hiring practices.

Diamond's responses address why decolonization continues to be an important topic for ethnomusicology. She adds:

I think that we need to create encounters within the discipline that will reveal the normalization of perspectives that are Euro-American-centric, perspectives that tend to be privileged. It seems to me that we do this in fieldwork on an individual basis. We have contacts with communities, we understand different perspectives and see how tough inequity is when one is on the ground. When we get back to our comfortable academic spaces, the discourse changes. I'm hoping we can create some encounters within SEM, and I think it's happening slowly.

Chávez, Luis, and Russell P. Skelchy. 2019. Decolonization for ethnomusicology and music studies in higher education. Action, Criticism, and Theory for Music Education 18 (3): 115-43. https://doi.org/10.22176/act18.3.115 
My happiest moment at the 2016 SEM conference in Washington, [was] the round dance that the indigenous Section organized to support the Dakota Pipeline Protests ... they raised almost $\$ 1000$ in 10 minutes and sent it out to those folks. I think that commitment to action as well as talk, that was a very good moment in the Society for Ethnomusicology. I think a commitment to action is something we struggle with because it's hard to get consensus on issues, but I think from within the smaller groups, the SIGs [or Special Interest Groups within SEM] and the Sections [areas of interest] that do have a deeper knowledge of a particular cultural perspective ... there may be some initiative and some encounters that are created by those groups. I think that's a very good thing for SEM.

Encounters within the discipline are central to how Diamond envisions the process of decolonizing ethnomusicology. She begins by suggesting the need to address Eurocentric and privileged positions that exist when ethnomusicologists return to their departments after completing their time in the field. Diamond's comments allude to the ways that settlerism and ideas surrounding property and ownership lend themselves to the authority to produce knowledge and representations. Positions in universities remain privileged because of ongoing ties to settlerism, which highlight the continuities between the U.S. higher education system and its role in sustaining settler-dominated academic spaces and European epistemic assumptions through ownership of curriculum, research practices, and knowledge production. As indigenous scholars have noted, settler colonialism is premised on an education system designed not to serve indigenous interests and, in many cases, works against them (Teves et al. 2015, 271, 309; Smith 2008). Diamond correctly points out that within SEM, special interest groups and student sections can provide impetus for more substantive encounters, for instance, the Dakota Access Pipeline at Standing Rock and the indigenous music special interest group. This represents one example of an encounter within SEM that would not have taken place without the initiative of the indigenous music special interest group.

Another former SEM president (2007-2009), Deborah Wong, also responded to these issues. As Wong states,

The obvious reason is our history is colonial. It's not just our discipline but many others, especially anthropology. All of that doesn't need to be rehearsed. I have very mixed feelings about my home discipline, I'm a card-carrying SEM member and an ethnomusicologist for life, and I'm never going to be stepping back from that, but it doesn't mean that I'm not constantly impatient with my own home. I think that's an important thing to acknowledge. At its best, I think ethnomusicology is a type of utopian discipline in the sense that we are always

Chávez, Luis, and Russell P. Skelchy. 2019. Decolonization for ethnomusicology and music studies in higher education. Action, Criticism, and Theory for Music Education 18 (3): 115-43. https://doi.org/10.22176/act18.3.115 
hoping for more from ourselves, imperfect so we inevitably are. Ethnomusicologist[s] tend to be utopian in the hopes for ourselves and our discipline ... we are willing to address the tension of where we are and where we could be. There's a reason why ethnomusicologists are so obsessively reflexive about ourselves and the discipline. Over and over again in the journal we're publishing about "What is Ethnomusicology?"

Again, I say that with honor and affection about my own discipline. For me personally, I love the way ethnomusicologists at some level are willing to think about the politics of the real. We are willing to think about things that are actually done on the ground. And could be done on the ground. We're very cautious about taking those steps sometimes but we're also solidly grounded in the experience of the real and lived experiences and the ways that musicians and our interlocutors and friends and teachers live in a real world. At the same time, I think we're also willing to push for change as a discipline. There's no question that our discipline has undergone a lot of change in the decades it's existed, and I'm thinking especially since the 1950 s with North American-based ethnomusicology. So why should we be concerned? Well, because decolonization is the pressing issue of our time, and at that level I think we're well equipped to address it. And yet we haven't.

Similar to Diamond, Wong's conflicted feelings about ethnomusicology suggests that both past presidents see ample need for change. Although Wong was optimistic about the discipline's willingness to change and address the tensions that exist within, there remain significant challenges to how and when such changes will (or can) be enacted. As Wong suggests, although SEM should be well equipped to address the issue of decolonization, there is substantive push back against such change within the organization. Resistance to change may have to do with coloniality of power that exists within SEM, which simultaneously resists decolonization while promoting it. This type of duality in the organization, which Wong describes as "cautious" steps, means that any efforts at change come very slowly, if it at all. Wong also discussed the importance of ethnography to the discipline and focused on the types of ethnographies we create. This point is a disciplinary challenge to re-examine how ethnography reinforces colonial relationships and to explore other research methodologies, some of which we present in the conclusion of this article in the projects section.

Harris Berger, SEM's president from 2011-2013, also addressed decolonization as an important issue for ethnomusicologists. According to Berger,

Power is a central concern for anyone who is interested in the study of expressive culture. Decolonization ethnomusicology is about identifying and dismantling the colonial assumptions and practices that shape the work we do in our field. It's a central current in the broad reorientation toward critical scholarship

Chávez, Luis, and Russell P. Skelchy. 2019. Decolonization for ethnomusicology and music studies in higher education. Action, Criticism, and Theory for Music Education 18 (3): 115-43. https://doi.org/10.22176/act18.3.115 
that has been going on for many years. Having grown up in the U.S. and taught there since the mid-1990s, I moved to Canada in 2016. Here in Canada, the discourse of decolonization is much more prevalent than it is in the States. And it's not only an academic discourse; you find the notion of decolonization in mainstream media and politics as well. One could not say that Canadian ethnomusicology or Canadian society in general have decolonized, not by a long way, but the fact that this is part of the wider political discourse here is important, and it essential for the US to move in the same direction.

In thinking about power and disciplinarity, the place to start is with this: our naïve understanding of what an academic discipline is. The most basic vision we have of disciplines is that they are defined by their study objects ... Disciplines are groups of people and their practices, their discourses, their institutions. Because every discipline has an intellectual history and a set of contemporary practices, it's never separate from its social context and the discourses of power that operate there. In North America and Western Europe, ethnomusicology primarily emerged from anthropology and musicology. As the field that studied the colonial other and sought to help in the management of empire, anthropology's colonial legacy could not be more obvious. Musicology's colonial legacy is equally direct, though perhaps slightly less obvious, as its project was to study and celebrate the elite musics of Europe.

The second question we posed to the interviewees was: What were some of the challenges you faced in introducing (or implementing) decolonizing policies? Or, what are some of the challenges facing decolonizing policies?

Diamond: The short answer is none. In general, people are eager to see some changes. They sometimes don't have the position to do it or maybe just the willingness to break the norm but are happy to see others initiate change, in my experience. I think I took baby steps in that regard as SEM President. I had a couple of things in mind. I wanted to raise the profile of public sector members and organizations. And I certainly wanted one of the president's roundtables to consider decolonization. I called it an "Indigenous Theory" panel because I didn't want it to be cast as "Well let's hear about the political issues." I wanted it to be hardcore ethnomusicology stuff, to address broad conceptual issues that theory implies. How might indigenous theory change our thinking? How does this change our approach both ethically and conceptually? I think what the Board can do well is to encourage those groups that are invested in certain perspectives and certain issues, to give them space, to give them support.

Wong: In my own efforts to be a change agent, whether it's as SEM president or here in my community of Riverside, I'm in it for the long game. Let me put it that way. We all come up with our personal strategies about how to create change. I'm not interested in broad general talk about social justice. I actually want to work about specific things in specific ways. I very much believe in working from within. I think that change may occur in dramatic public moments, but most of the important change happens by sitting at the table over and over and over again. And I always expect significant change to be slow

Chávez, Luis, and Russell P. Skelchy. 2019. Decolonization for ethnomusicology and music studies in higher education. Action, Criticism, and Theory for Music Education 18 (3): 115-43. https://doi.org/10.22176/act18.3.115 
(laughed), but I think we also need to be ready to push in moments of opportunity when things can move along more quickly.

Two key issues Wong addressed during her tenure as SEM president were the society logo of the "ethno-man" and holding SEM conferences outside of the United States, both of which represented Wong's approach to reforming the society by working from within. Since the 2009 SEM conference in Mexico City, there have not been any SEM national conferences held outside the United States. General anxieties persist about holding the conference outside the U.S. because of, among other reasons, cost, language barriers, and safety concerns. These anxieties expose a xenophobia among some SEM members in the United States and suggest that SEM remains predominantly a U.S.-centered organization serving U.S. institutions. Continuing to explore the possibility of holding the SEM conference internationally encourages the participation of non-U.S. scholars who would provide a greater diversity of worldviews and scholarship.

Wong also addressed the issue of the society's ethno-man logo, which was initially brought up for referendum by Timothy Rice, another former SEM president (2003-2005). The measure to remove ethno-man as the symbol of the society failed to pass by a small margin. The years-long process to remove an obvious symbol of ethnomusicology's colonial past exhibits how challenging it can be to address the colonialist legacies within North American music studies. These types of "mystified images," as Aníbal Quijano (2007) describes, are systematically imposed through colonial patterns of producing knowledge and meaning that serve as efficient means of social and cultural control (169).

Wong: One of the things Tim Cooley did [as a member of the SEM executive board] ... was [change] the font that was used on the cover of the journal ... [or] what we eventually began to call "the caveman font." Tim Cooley said, "We really need to get rid of it," so we did basically. These may seem like ridiculously particular examples but, of course, they're not, right? We know that representation is not small in the end in any means. ... As president, one of the things I was very much involved in was the decision to meet in Mexico City; that was the annual meeting in 2009. Like our other meetings, it took several years to put together. SEM is an international scholarly society. Seventy-five percent of our membership is North American, and U.S. rather than Canada; those numbers have remained constant over time. One of the big questions about SEM is whether it is actually a U.S./North American organization or is it an international organization.

Harris Berger suggests another area of institutional change within the discipline is to address the issue of diversity.

Chávez, Luis, and Russell P. Skelchy. 2019. Decolonization for ethnomusicology and music studies in higher education. Action, Criticism, and Theory for Music Education 18 (3): 115-43. https://doi.org/10.22176/act18.3.115 
Berger: Diversity is in some ways a kind of mild, polite word for anti-racism, anti-sexism, anti-hate. At its worst, the term diversity can operate like a euphemism. It's not a terrible word and it does have a place, but it would be better if we could say, "we are looking to develop work that combats racism, sexism, homophobia, and capitalism." As SEM president, issues of power and equity were my primary focus. Building on the efforts that had a long history in the Society, I was able work with the SEM Board to put together some initiatives-the Diversity Action Committee and its programs, in particular-that I am proud of. However, I am realistic about the limits of what I and my colleagues were able to do. SEM doesn't exist in a vacuum. It is a medium-sized scholarly organization that is situated within the institutional context of many national academies and is shaped by larger social contexts. There is no way that SEM can escape the power relations that are baked into those institutions and contexts. This isn't to say that we should simply give up, but it would be naïve to think that our organization is immune to these powerful forces.

The third question we posed to the interviewees was: What are the implications of decolonization for music departments? What would a decolonized music department look like for you?

Diamond: It's tough, isn't it? At the several universities where I have taught, my colleagues are people I think of as liberal thinkers in some ways, yet some push back at the strangest times. You mention the musicologists and composers, but I find that it's the performers of the Western art music tradition that are sometimes the hardest to convince. They are so into-and they need to bethey're so into the repertoire that they want to be perfect at, and some have no energy left to think about larger social issues. One strategy for opening a conversation is to talk, not about music, but about health. How does one stay ablebodied and able-voiced as a musician? If a singing teacher were to suggest that bel canto is the only healthy mode of voice production, ethnomusicologists might point to other evidence. Linking health to one cultural tradition, of course, inadvertently casts all other practices as unhealthy. That can be a revelation for some. If you can create an encounter that is about an issue that a colleague is concerned about, then, it's more fruitful.... It's a long struggle... I do think that since that Hawaiian (SEM conference) meeting, decolonization has become a more prominent issue. But there are challenges to keeping it on the agenda. When I said to a colleague that I was going to do the indigenous theory roundtable, they said "Well didn't we already do that in Hawaii?" As if it could only be done once.

Wong: I've flipped back and forth between long, slow gradual work. And it feels so slow and it feels so gradual. And part of me wants to step outside of it. Part of me thinks music departments are never going to be decolonized and still be music departments ... I know for me having multiple homes has been essential, not only for personal morale but also in keeping our body and soul together, but also in being strategically effective. To operate only in a music department can be really exhausting in many institutions ... not all music de-

Chávez, Luis, and Russell P. Skelchy. 2019. Decolonization for ethnomusicology and music studies in higher education. Action, Criticism, and Theory for Music Education 18 (3): 115-43. https://doi.org/10.22176/act18.3.115 
partments. Just a footnote here for a second, ethnomusicology has reached a point of historical development within American higher education where a number of ethnomusicologists have now reached roles as institutional administrators, whether its department chairs or deans or directors of schools of musics. All of those things have happened that do suggest broader and deeper change; again, it's gradual but it's quite pronounced. And that's pretty exciting. I say that as a former department chair. The first ethnomusicologist to serve as chair of my department, the first woman to serve as chair of my department, the first faculty member of color to serve as chair of my department! Yeah, so some things are changing gradually.

Berger: On a basic level, decolonizing a music department or a music school, or a music program-and [ethnomusicologists] are in all kinds of academic units-means recognizing the colonial dimensions of traditional music education, rethinking that project, and having a group of faculty and students who understand music in its widest dimension. Music happens everywhere on planet Earth, the Western conservatory tradition is not central in any way, shape, or form, and a decolonized music department would teach music from a wide variety of cultures and traditions. Having a decolonized music department would mean having a diverse group of faculty and students researching, teaching, and studying music, with a varied set of relationships to the musics that they work on.

This section has illustrated attitudes on the decolonization of music studies by three recent past presidents of the Society for Ethnomusicology, a U.S.-based organization of music scholars. Although their viewpoints are indicative of how the organization has engaged with decolonization in recent years, in no way does this represent the entirety of opinions or possibilities. For instance, further work can be done to assess the attitudes of other music studies organizations in the U.S. such as the American Musicological Society (AMS) and the Society for Music Theory (SMT). Further studies should also explore how other international music organizations have addressed decolonization within their own fields or geographic areas.

\section{Conclusion}

In the weeks following the 2016 U.S. presidential election and the SEM national conference, The SEM Board and Council leadership released this statement:

It has become clear that our work is more important now than ever. The uncertain future of this new era, where powerful words and their aftershocks have put vulnerable groups at risk both symbolically and, in some cases, visibly, within our own communities, is a mandate for us to publicly reaffirm our long held values of inclusivity and tolerance; to disseminate our research, teaching, and

Chávez, Luis, and Russell P. Skelchy. 2019. Decolonization for ethnomusicology and music studies in higher education. Action, Criticism, and Theory for Music Education 18 (3): 115-43. https://doi.org/10.22176/act18.3.115 
activism in ways that are more public and more political; to share best practices; and to offer our voices and our commitment to the communities in which we live and work, local and global, wherever and whenever possible. ${ }^{2}$

However well-intentioned this statement is, we question how it challenges the status quo and does not simply reinforce it. As U.S. ethnomusicologists work toward new ways of applying this type of activist language, what unique approaches may ethnomusicology offer at this moment?

This article in Action, Criticism, and Theory for Music Education represents a critical analysis of how ethnomusicologists in the U.S. have engaged with decolonization. Focusing on the keywords, decolonization and ethnomusicology, we explore a new discourse about structural changes in ethnomusicology that have wider political ramifications for music studies. Inspired by Linda Tuhiwai Smith's (2008) projects for decolonizing research methodologies, we have contributed below a list of projects toward decolonizing music education. Each offers possibility and creates new spaces for a multiplicity of knowledges and the possibility of undoing Western academic hierarchies of knowledge (Sefa Dei 2010, 77). Creating these spaces also accounts for the project of provincializing European thought made universal by modern imperialism and (third-world) nationalism (Chakrabarty 2000). The projects and approaches proposed in this section of the essay begin to address what decolonization involves and how it can be done. We provide the following list for experimentation in the classroom.

\section{Practical Approaches and Projects:}

1. Shaping listening spaces: Decolonizing physical space in the classroom also refers to decolonizing mental space in terms of listening to and understanding music. Here we are thinking about how classroom space is organized, and more specifically how teachers continue to represent the authority in dispensing knowledge versus having students engage with one another or explore their individual understanding of the material.

2. Re-thinking ethnography: Although ethnography is a predominant methodology, we suggest listening to indigenous epistemologies that explore different nonwestern understandings of knowledge production. We aim to draw theory from practice that changes our vantage points as researchers in a subject-object relationship. By engaging with indigenous epistemologies, we open ourselves to accepting multiple truths, rather than thinking in universalist ways.

Chávez, Luis, and Russell P. Skelchy. 2019. Decolonization for ethnomusicology and music studies in higher education. Action, Criticism, and Theory for Music Education 18 (3): 115-43. https://doi.org/10.22176/act18.3.115 
3. Exploring storytelling and oral history: Rather than privileging a visualist ideology in ethnography, we propose a "sounding" approach that includes a focus on storytelling. The dialogic aspect of storytelling establishes conversations beyond the writer and the text to include a polyphony of voices. Besides focusing on descriptions of musical performances, how can music educators use oral histories to reshape the narratives of our research? How can these oral histories be interjected into our texts or put in dialogue with our voice?

4. Repatriation of songs: Currently there are a number of songs compiled in archives that are stored in institutional settings (universities, museums, personal collections, etc.) that should be repatriated (handing ownership of intellectual property over) to communities that originally performed these pieces. Practicing repatriation also makes researchers responsible for the repercussions of "taking" from people and field sites (Fox 2014; Gray 2015).

5. Bridging music studies and ethnic studies: Given that both disciplines are already interdisciplinary, music pedagogy can benefit from approaches (or advances) in ethnic studies that already address issues of social justice, decolonization, and representation. The emphasis on overtly political research done in ethnic studies suggests ways for ethnomusicologists and other music educators to gain a more sophisticated vocabulary and ways of thinking about people of color. We wish that ethnic studies classes become further embedded in the core curriculum of music studies.

6. Community-based participatory research: This is the process of including multiple members of a community in data gathering. This project engages with indigenous and local communities by ceding ownership of representation of their pasts and ways of understanding (Atalay 2012, 4). This methodology acknowledges a community approach to understanding performance and decenters the researcher as a gatekeeper to knowledge.

7. Collaborative projects within (and outside) the music department: Projects on an undergraduate and graduate level may include collaboration between ethnomusicologists, composers, and musicologists, which can take the form of publications, musical compositions, or live performance. The benefit of these collaborations could be furthering a dialogue about decolonization in music departments that addresses ways of listening, composing, and thinking about music studies.

Chávez, Luis, and Russell P. Skelchy. 2019. Decolonization for ethnomusicology and music studies in higher education. Action, Criticism, and Theory for Music Education 18 (3): 115-43. https://doi.org/10.22176/act18.3.115 
8. Exploring decolonized performance: What would a decolonized performance of non-Western music look like? For instance, how do current practices of costuming in non-Western ensembles contribute to essentializing people and cultures? What are we doing when we perform non-Western music? Why is nonWestern music taught in a decontextualized setting? How is authority established through the performance of non-Western musics? Although authors in ethnomusicology and music education have addressed some of these issues (e.g., Solís 2004, Campbell 2005), there remains work to be done in engaging with how nonWestern music is learned and re-presented in classrooms, music ensembles, and performance settings.

9. Listening as a way of decolonizing: What would a decolonized ear training class focus on? Currently at the undergraduate level, most ear training classes focus on listening that favors the perspective of Western art music. What if this were expanded to include listening outside of Western tonal relationships, for instance, listening for social and cultural associations? Decolonizing listening practices suggests an important beginning point for decolonizing curriculum and music departments generally.

10. Community engagement: Many academics today are evaluated for job positions based on their publications, or more accurately, how well they have published in respected journals or with particular publishers. What if this criteria were changed to include community engagement or service (besides campus community service)? We envision publications that reflect how music scholars engage with community projects (i.e., projects that directly or immediately benefit communities, or what we previously mentioned as community-based participatory research). Should we, as a scholarly community, be making more efforts to ensure that our research has more use-value for the communities with whom we work?

\section{Acknowledgments}

We thank Beverley Diamond, Deborah Wong, Harris Berger and Timothy Cooley for agreeing to be interviewed for this article, and Guillermo Rosabal-Coto, Deborah Bradley and the anonymous reviewers for their helpful suggestions and comments. Some of the research for this paper conducted by Russell Skelchy was related to the Cultures of Occupation in Twentieth-Century Asia (COTCA) Project, and he received funding from the European Research Council under the European Union's Horizon 2020 research and innovation program (Grant Number 682081).

Chávez, Luis, and Russell P. Skelchy. 2019. Decolonization for ethnomusicology and music studies in higher education. Action, Criticism, and Theory for Music Education 18 (3): 115-43. https://doi.org/10.22176/act18.3.115 


\section{About the Authors}

Luis Chávez received the $\mathrm{PhD}$ in ethnomusicology with a Designated Emphasis in Native American Studies from the University of California, Davis. Chávez holds a bachelor's degree in music with an emphasis on guitar performance, and a master's degree in music history and literature from the California State University, East Bay. He is an ethnomusicologist whose research focuses on sound, music, and dance in Mexico.

Russell P. Skelchy is the ERC Research Fellow leading the Sounds of Occupation stream in the Cultures of Occupation in Twentieth-Century Asia (COTCA) project at the University of Nottingham (UK). He received the PhD in Ethnomusicology and MA in Southeast Asian Studies at the University of California, Riverside. His research interests include imperialism, decolonization, multiracial studies, popular music (sub)cultures, sound studies and gender studies. He is a recipient of a Fulbright US Scholar grant (2017-2018), Fulbright Institute for International Education Fellowship (2011-2012) and the University of California Pacific Rim Research Program Fellowship (2011-2012). His recent publications have appeared in the Journal of Popular Music Studies, Ethnomusicology, Asian Music, the Journal of World Popular Music and he has contributed a chapter to the volume Vamping the Stage: Female Voices of Asian Modernities (University of Hawai'i Press, 2017).

\section{References}

Anderson, Joan M., Koushambhi Basu Khan, and Sheryl Reimer-Kirkham. 2011. Community research from a post-colonial feminist perspective: Exemplars from health research in Canada and India. In Feminist community research: Case studies and methodologies, edited by Gillian Creese and Wendy Frisby. Vancouver: UBC Press.

Atalay, Sonya. 2012. Community-based archaeology: Research with, by and for Indigenous and local communities. Berkeley: University of California Press.

Barker, Joanne. 2017. Critically sovereign: Indigenous gender, sexuality and feminist studies. Durham: Duke University Press.

Barz, Gregory F. and Timothy J. Cooley. 2008. Shadows in the field: New perspectives for fieldwork in ethnomusicology, 2nd edition. New York: Oxford University Press.

Bradley, Deborah. 2015. Hidden in plain sight: Race and racism in music education. In The Oxford handbook of social justice in music education, edited by Cathy Benedict, Patrick K. Schmidt, Gary Spruce and Paul G. Woodford. New York: Oxford University Press.

Chávez, Luis, and Russell P. Skelchy. 2019. Decolonization for ethnomusicology and music studies in higher education. Action, Criticism, and Theory for Music Education 18 (3): 115-43. https://doi.org/10.22176/act18.3.115 
Brown, Robert E. 1995. World music as it was in the beginning, is now and really should be. In Teaching musics of the world, edited by Margot Lieth Philipp and Andreas Gutzwiller. Affalterbach, Germany: Philipp Verlag.

Bishop, Russell. 2005. Freeing ourselves from neo-colonial domination in research: A Kaupapa Maori approach to creating knowledge. In The SAGE handbook of qualitative research, 3rd edition, edited by Norman K. Denzin and Yvonna S. Lincoln. Thousand Oaks, CA: Sage.

Campbell, Patricia S., et al. 2005. Cultural diversity in music education: Directions and challenges for the 21st century. Brisbane: Australian Academic Press.

Chakrabarty, Dipesh. 2000. Provincializing Europe: Postcolonial thought and historical difference. Princeton, NJ: Princeton University Press.

Clifford, James. 1986. Introduction. In Writing culture: The politics and poetics of ethnography, edited by James Clifford and George E. Marcus. Berkeley: University of California Press.

Cook-Lynn, Elizabeth. 1998. History, myth and edentity in the new Indian story. In The SAGE handbook of qualitative research, 3rd ed., edited by Norman K. Denzin and Yvonna S. Lincoln. Thousand Oaks, CA: Sage.

Fox, Aaron. 2014. Repatriation as re-animation through reciprocity. In The Cambridge history of world music: Vol. 1 (North America), edited by Philip Bohlman. Cambridge University Press.

Graham, Renee. 2017. Bound by history: Universities and slavery. Radcliffe Magazine. https://www.radcliffe.harvard.edu/news/radcliffe-magazine/ bound-history-universities-and-slavery

Gray, Robin R. R. 2015. Ts'msyen revolution: The poetics and politics of reclaiming. Doctoral dissertation, University of Massachusetts, Amherst.

Gustafson, Ruth I. 2009. Race and curriculum: Music in childhood education. New York: Palgrave Macmillan.

Guha, Ranajit. 1997. Subaltern studies reader, 1986-1995. Minneapolis: University of Minnesota Press.

Hess, Juliet. 2017. Equity and music education: Euphemisms, terminal naivety and Whiteness. Action, Criticism and Theory for Music Education 16 (3): $15-47$.

Chávez, Luis, and Russell P. Skelchy. 2019. Decolonization for ethnomusicology and music studies in higher education. Action, Criticism, and Theory for Music Education 18 (3): 115-43. https://doi.org/10.22176/act18.3.115 
Kunst, Jaap. 1950. Musicologica: A study of the nature of ethnomusicology, its problems, methods and representative personalities. The Hague: Martinhus Nijhoff.

LaDuke, Winona, and Sean Cruz. 2011. The militarization of Indian country: From Geronimo to Bin Laden. Minneapolis: Honor the Earth.

Maldonado-Torres, Nelson. 2007. On the coloniality of being. Cultural Studies 21 $(2-3): 240-70$.

Mignolo, Walter. 2000. Local histories/global designs: Coloniality, subaltern knowledges, and border thinking. Princeton, NJ: Princeton University Press.

Nelson, Melissa K, ed. 2011. Original instructions: Indigenous teachings for a sustainable future. Rochester, VT: Inner Traditions.

Nettl, Bruno. 2010. Nettl's elephant: On the history of ethnomusicology. Urbana: University of Illinois Press.

Quijano, Aníbal. 2000. Coloniality of power, Eurocentrism, and Latin America. Nepantla: Views from South 1 (3): 533-80.

Quijano, Aníbal. 2007. Coloniality and modernity/rationality. Cultural Studies 21 $(2-3): 168-78$.

Titon, Jeff Todd. 2015. Applied ethnomusicology: A descriptive and historical account. In Oxford Handbook of applied ethnomusicology, edited by Svanibor Pettan and Jeff Todd Titon. Oxford: Oxford University Press.

Radano, Ronald, and Tejumola Olaniyan. 2016. Introduction: Hearing empireimperial listening. In Audible empire: Music global politics, critique, edited by Ronald Radano and Tejumola Olaniyan. Durham: Duke University Press.

Rodriguez, Ileana, ed. 2001. Latin American subaltern studies reader. Durham: Duke University Press.

Rosabal-Coto, Guillermo. 2014. I did it my way! A case study of resistance to coloniality in music learning and socialization. Action, Criticism and Theory for Music Education 13 (1): 155-87.

Samudzi, Zoé, and William C. Anderson. 2018. As Black as resistance: Finding the conditions for liberation. Chico, CA: AK Press.

Chávez, Luis, and Russell P. Skelchy. 2019. Decolonization for ethnomusicology and music studies in higher education. Action, Criticism, and Theory for Music Education 18 (3): 115-43. https://doi.org/10.22176/act18.3.115 
Saranillio, Dean Itsuji. 2015. Settler colonialism. In Native studies keywords, edited by Stephanie Nohelani Teves, Andrea Smith and Michele H. Raheja. Tucson: University of Arizona Press.

SEM Student News. 2016. "Decolonizing Ethnomusicology." SEM Student News 12(2). https://cdn.ymaws.com/www.ethnomusicology.org/resource/gr oup/dc75b7e7-47d7-4d59-a66o-19c3eof7c83e/publications/SEMSN12.2.pdf

Sefa Dei, George J. 2010. Teaching Africa: Towards transgressive pedagogy. New York: Springer Press.

Schippers, Huib. 2010. Facing the music: Shaping music education from a global perspective. Oxford: Oxford University Press.

Simpson, Leanne Betasamosake. 2012. Dancing on our Turtle's Back. Winnipeg: Arbeiter Ring Publishing.

Smith, Linda Tuhiwai. 2008. Decolonizing methodologies: Research and Indigenous peoples. London: Zed Books.

Solís, Ted. 2004. Performing ethnomusicology: Teaching and representation in world music ensembles. Berkeley: University of California Press.

Teves, Stephanie Nohelani, Andrea Smith and Michele H. Raheja, eds. 2015. Native studies keywords. Tucson: University of Arizona Press.

Titon, Jeff Todd. 2015. Applied ethnomusicology: A descriptive and historical account. In The Oxford handbook of applied ethnomusicology, edited by Svanibor Pettan and Jeff Todd Titon. New York: Oxford University Press.

Tuck, Eve and K. Wayne Yang. 2012. Decolonization is not a metaphor. Decolonization: Indigeneity, Education \& Society 1 (1): 1-40.

Wittner, Lawrence S. 2015. Why tuition-free college makes sense. Truthout. http://www.truth-out.org/opinion/item/33473-why-tuition-free-collegemakes-sense

\section{Notes}

${ }^{1}$ https://www.radcliffe.harvard.edu/news/radcliffe-magazine/bound-historyuniversities-and-slavery

2 "Position Statement in Response to the 2016 US Presidential Election." https://www.ethnomusicology.org/news/325267/Position-Statement-inResponse-to-the-2016-U.S.-Presidential-Election.htm

Chávez, Luis, and Russell P. Skelchy. 2019. Decolonization for ethnomusicology and music studies in higher education. Action, Criticism, and Theory for Music Education 18 (3): 115-43. https://doi.org/10.22176/act18.3.115 